\title{
Impact of Nifty BEeS on Select Gold Exchange Funds with Reference to NSE India
}

\author{
Dr S Subbalakshmi \\ MBA, PhD (Finance), \\ Assistant Professor, \\ Rishi UBR PG College for Women
}

\begin{abstract}
The growth of exchange traded funds in India is in ascent stage. Investors who cont take the advantage with direct investments they can take the ETF'S help. The investment spectrum of ETF'S is increasing day by day. In this study how sectorial indices are affecting the ETF'S for the period of 2016 to 2021. The study measured the relationship of select Gold ETFs with the Nifty Bees by applying the vector error correction model. The study result reveals that all the selected ETFs are having the significant relationship with the Nifty Bees. The Ordinary least square method has been used to know the impact of Nifty Bees on the select Gold ETFs and observed that all the Gold ETFs are having the significant impact by the benchmark of NSE India Nifty Bees. This paper is useful to the investors of ETF, mutual funds and regulators of the capital market.
\end{abstract}

\section{Keywords: Axis Gold, ETFs, IDBI Gold, Kotak Gold, Nippon and Nifty Bees}

\section{INTRODUCTION:}

ETFs have grown exponentially in the US market since the first ETF (SPDR S\&P500: SPY) was launched in 1993. In 2008 India, there were an equal number of ETFs in the sector and diversified ETFs, but the overall market size for the ETFs sector was only 13 per cent of the diversified ETF's average market value. Gold Exchange Traded Funds or Gold ETFs are mutual fund schemes open to the public that are always based on constant changes in gold prices. Physical gold, on the other hand, produces no income. The physical gold strain is also heavy. Gold ETFs give investors an exposure to the gold market. Investors who want to overcome inflation in the long run are a great investment choice. In comparison, gold as a currency is less risky than equities. The equivalent of 1 gram of gold is 1 gold ETF unit. It offers you the double value of both stock trading and gold trading. Some of the funds capitalized on gold bullion to closely monitor market performance. In relation to the price of physical gold, the value of gold ETF is increasing / decreasing. Not only do they not compromise integrity, they also promise a clear availability across the country.

For investors seeking to diversify their portfolio by exposing themselves to the gold market, Gold ETFs are appropriate. This investment is low-risk and appropriate for conservative investors. The money goes to the 99.5 percent purity Gold Bullion. Even if traded on the stock exchange, ETF gold is a low-risk investment. People who are not interested in investing storage money and additional taxes, such as physical gold, can also opt for gold ETFs. As a back-end security, physical gold supports Gold ETF If you purchase Gold ETF, for example, you purchase gold from the back end of the individual or company. They also give investors guarantees on the purity of gold. In the NSE (National Stock Exchange) Gold BeES, for example, closely monitors the current market rates, called gold spot prices. The NSE requires the Authorized User or Member to manage the acquisition and sale of gold to set up ETFs, usually large company / companies. Continuous trading and supervision of 'authorized Members' ensures that the cost of gold and ETFs remains the same. Thus, the study made an attempt to know Role of Benchmark indices effect on Exchange Trade Funds with reference to gold ETFs.

\section{REVIEW OF LITERATURE:}

Umarani R \& Deepa D (2014): The Exchange Traded Fund (ETF) is one of the most creative financial exchange products. ETFs are required by investors in India and numerous Indian investors and therefore do not take into account ETFs. When comparing the markets of other countries, the ETFs were limited to specific indices. 75 per cent of ETFs in the US have an impact on the total turnover of the US stock exchange, but only 25 per cent of ETFs in India have an impact on the total sales volume of the Indian stock market. Indian bond regulators can only control how ETFs are traded and sensitize Indian traders to risk-free ETFs.

Sudindra (2015): This paper presents an empirical analysis of the results of Gold Traded Funding. The study shows that the alpha of Jensen is unfavourable to all funds other than the Reliance Gold Fund. This results in over-returns from the Spot Gold Fund by the Reliance Gold ETF. The analysis also shows that ICICI and Reliance Gold ETF performance index funds have been put on the market over the last two years. Overall, the study shows that in India, only two out of nine gold ETFs traded in NSE have yielded better results than market output.

Purohit et al (2015): The objective of the proposed research is to measure this error using the NSE approach and then determine its effect on investment. The ETF has opened up opportunities for individual and institutional investors to invest. Investors are able to expose their investments via ETF to overseas stocks and sectoral market instruments, and this capability has many benefits, such as lower prices, real-time trading, and rapid exposure to other market instruments. However, these ETFs suffer from a tracking error, whereby the average return of the ETFs differs from the return of their assets referred to above.

Narend M. Thenmozhi (2019): Regardless of their underlying benchmark, we are investigating the influence of the country's traded funds (ETFs) on the country's bond indices. The study also document the reversal of causal dynamics between ETFs and 
inventory indices in the region. Even after global influence, market volatility, FII flows, foreign-institute currency and Indian ETF assets have been regulated, the results are robust. The findings of the study have an impact on both developing and established markets for global investors and policy makers. It will be imperative for policy makers to track national ETF flows to the core nation, as the withdrawal of ETFs may have a cascading effect on the economy.

Prabhdeep Kaur and Jaspal Singh (2020): This paper discusses, using a set of standard threshold co-integration figures, the relative effectiveness of gold traded funds (ETF) against Indian spot gold and gold futures. These results demonstrate the longterm convergence of gold ETFs, spot gold, gold ETFs and gold futures. In addition, spot and future market fluctuations have been shown to contribute to the ETF market and thus provide scope for the implementation of efficient ETF trading strategies. The research also explores why the relative inefficiency found in the ETF price may be considered.

\section{OBJECTIVE OF THE STUDY:}

1. To know the relationship of select ETFs with the ETF benchmark of NSE India

2. To know the impact of NSE ETF benchmark on select ETFs

\section{HYPOTHESES OF THE STUDY:}

$\mathrm{H}_{01}$ : There is no long run relationship exist between the ETFs' and Benchmark (Nifty bees)

$\mathrm{H}_{02}$ : NSE benchmark (Nifty Bees) has no impact on the select ETFs'

\section{SCOPE OF THE STUDY:}

The study focused on the Role of Benchmark indices effect on Exchange Trade Funds with reference to NSE India. It has considered the four Gold Exchange Trade Funds (ETFs) based on higher Market capitalization from the period of 2016-17 to 2020-21. The following are the Gold Exchange Trade Funds were considered,

Nippon Gold, AXIS Gold, IDBI Gold, Kotak Gold and Nifty Bees

\section{RESEARCH METHODOLOGY:}

This study is designed to analyze the effect of gold ETFs on the Indian stock market with reference to NSE India. Its aim is to identify the relationship between Nifty and the Gold ETF. In addition, the objective is to determine the impact of selected gold ETFs on the Indian Bees Nifty. The data used for this research are obtained from NSE India. Secondary data has been collected and used for this research. The variables used are explained in detail in the following table.

Table -1: Variables considered for the objectives

\begin{tabular}{|l|l|}
\hline Independent Variable & Dependent variable \\
\hline \multirow{4}{*}{ Nifty Bees } & Nippon gold \\
\cline { 2 - 2 } & AXIS gold \\
\cline { 2 - 2 } & IDBI Gold \\
\cline { 2 - 2 } & Kotak Gold \\
\hline
\end{tabular}

Following are the statistical tools considered for the study to justify the objective

Stationarity and Unit Root Tests: Unit root tests are critical for analyzing time serial data regression because of the fact that they are non-stationary. The study examines the stationary of the variables using the root test developed by Dickey and Fuller (1981) with the Augmented Dickey-Fuller.

Vector Error Correction Model: The research used the Vector Error Correction Model (VECM) methodology to determine the relationship between the Exchange Trade Fund and the Indian stock market. In the case of variable stationary differences, VECM is a special case of VAR (i.e. lag (1)). The lag is selected using the minimum of the "Akaike Information Criteria" "Schwartz Information Criteria" (SIC) or "Hannan-Quinn Criteria" (HQC) criteria. The results of the VECM determine whether there is a long-term or short-term relationship between the variables. This has been achieved with econometric software.

Ordinary Least Square: The study used the Ordinary Least Square (OLS) technique to determine the effect of Nifty on Gold ETFs. The result of the OLS determines whether the NSE benchmark has a significant effect on the Gold Exchange Trade Funds.

\section{TABULATION OF DATA ANALYSIS:}

\section{Objective1: To know the relationship of select ETFs with the benchmark of NSE India}

In order to determine the relationship between the Exchange Trade fund and Indian stock market, the study used the technique of Vector Error Correction Model (VECM). The VECM is just a special case of the VAR for variables that are stationary in their differences (i.e., I (1)). The VECM can also take into account any co-integrating relationships among the variables. The lags are selected by using the minimum of the "Akaike Information Criteria" (AIC), "Schwartz Information Criteria" (SIC) and "HannanQuinn Criteria" (HQC). The results of the VECM identify whether exists of long or short run relationship between the variables.

Table- 2: VAR Lag Order Selection Criteria VAR Lag Order Selection Criteria 


\begin{tabular}{|c|c|c|c|c|c|c|}
\hline \multicolumn{7}{|c|}{ Endogenous variables: NIFTY AXISGOLD NIPPONGOLD IDBIGOLD KOTAKGOLD } \\
\hline \multicolumn{7}{|c|}{ Exogenous variables: $\mathrm{C}$} \\
\hline \multicolumn{7}{|c|}{ Sample: 1247} \\
\hline \multicolumn{7}{|c|}{ Included observations: 243} \\
\hline Lag & $\operatorname{LogL}$ & LR & FPE & $\mathrm{AIC}$ & $\mathrm{SC}$ & HQ \\
\hline 0 & -6913.730 & NA & 3.708518 & 56.94428 & 57.01615 & 56.97323 \\
\hline 1 & -5655.059 & 2455.186 & 1.449814 & 46.79061 & 47.22185 & 46.96431 \\
\hline 2 & -5615.994 & 74.59219 & 1.284514 & 46.67485 & 47.46546 & 46.99330 \\
\hline 3 & -5566.238 & 92.95970 & 1.057414 & 46.47110 & 47.62108 & 46.93430 \\
\hline 4 & -5285.423 & $513.0940^{*}$ & $1.281213^{*}$ & $44.36562 *$ & $45.87497 *$ & $44.97357^{*}$ \\
\hline \multicolumn{7}{|c|}{$*$ indicates lag order selected by the criterion } \\
\hline \multicolumn{7}{|c|}{ LR: sequential modified LR test statistic (each test at 5\% level) } \\
\hline \multicolumn{7}{|c|}{ FPE: Final prediction error } \\
\hline \multicolumn{7}{|c|}{ AIC: Akaike information criterion } \\
\hline \multicolumn{7}{|c|}{ SC: Schwarz information criterion } \\
\hline \multicolumn{7}{|c|}{ HQ: Hannan-Quinn information criterion } \\
\hline
\end{tabular}
Source: Secondary Data

Table depicts the lag order selection with respect to select ETF's and NSE benchmark. Here the LR test statistic was observed to fit at lag 4, similarly the Final Prediction error is fit at lag 4. Criterion such as AIC seems to be fit at lag 4, while Schwarz Information Criterion and Hannan Quinn Information Criterion are also observed to be fit at 4. Most of the criterion and test were observed to be fit at lag 4 which indicates that lag 4 was optimal model to estimate VECM.

Table-3: VECM for Relationship between Select ETF's and Nifty BEES

\begin{tabular}{|c|c|c|c|c|c|}
\hline \multicolumn{6}{|c|}{ Vector Error Correction Estimates } \\
\hline \multicolumn{6}{|c|}{ Sample (adjusted): 6247} \\
\hline \multicolumn{6}{|c|}{ Included observations: 242 after adjustments } \\
\hline \multicolumn{6}{|c|}{ Standard errors in ( ) \& t-statistics in [ ] } \\
\hline Cointegrating Eq: & CointEq1 & & & & \\
\hline $\operatorname{NIFTY}(-1)$ & 1.000000 & & & & \\
\hline & & & & & \\
\hline \multirow[t]{3}{*}{ AXISGOLD(-1) } & -0.310175 & & & & \\
\hline & $(0.09597)$ & & & & \\
\hline & {$[-3.23193]$} & & & & \\
\hline & & & & & \\
\hline \multirow[t]{3}{*}{ NIPPONGOLD(-1) } & -0.223965 & & & & \\
\hline & $(0.16517)$ & & & & \\
\hline & {$[-1.35593]$} & & & & \\
\hline \multirow[t]{3}{*}{ IDBIGOLD(-1) } & -0.048963 & & & & \\
\hline & $(0.03633)$ & & & & \\
\hline & {$[-1.34769]$} & & & & \\
\hline \multirow[t]{3}{*}{ KOTAKGOLD(-1) } & 9.007011 & & & & \\
\hline & $(2.20902)$ & & & & \\
\hline & {$[4.07737]$} & & & & \\
\hline & & & & & \\
\hline $\mathrm{C}$ & -1510.854 & & & & \\
\hline Error Correction: & D(NIFTY) & $\mathrm{D}(\mathrm{AXISGOLD})$ & $\begin{array}{c}\text { D(NIPPONGO } \\
\text { LD) }\end{array}$ & D(IDBIGOLD) & $\begin{array}{l}\text { D(KOTAKGO } \\
\text { LD) }\end{array}$ \\
\hline \multirow[t]{3}{*}{ CointEq1 } & -0.059174 & 0.037605 & -0.016631 & -1.019571 & -0.021960 \\
\hline & $(0.02669)$ & $(0.04542)$ & $(0.03057)$ & $(0.34619)$ & $(0.00714)$ \\
\hline & {$[-2.21668]$} & {$[0.82787]$} & {$[-0.54398]$} & {$[-2.94515]$} & {$[-3.07496]$} \\
\hline \multirow[t]{3}{*}{ D(NIFTY(-1)) } & 0.135953 & -0.109383 & 0.012671 & 1.519860 & 0.027607 \\
\hline & $(0.11888)$ & $(0.20229)$ & $(0.13615)$ & $(1.54169)$ & $(0.03180)$ \\
\hline & {$[1.14361]$} & {$[-0.54073]$} & {$[0.09306]$} & {$[0.98584]$} & {$[0.86807]$} \\
\hline \multirow[t]{3}{*}{ D(NIFTY(-2)) } & -0.115691 & -0.254130 & -0.067128 & 1.159223 & -0.008273 \\
\hline & $(0.11890)$ & $(0.20232)$ & $(0.13617)$ & $(1.54191)$ & $(0.03181)$ \\
\hline & {$[-0.97302]$} & {$[-1.25611]$} & {$[-0.49297]$} & {$[0.75181]$} & {$[-0.26008]$} \\
\hline
\end{tabular}




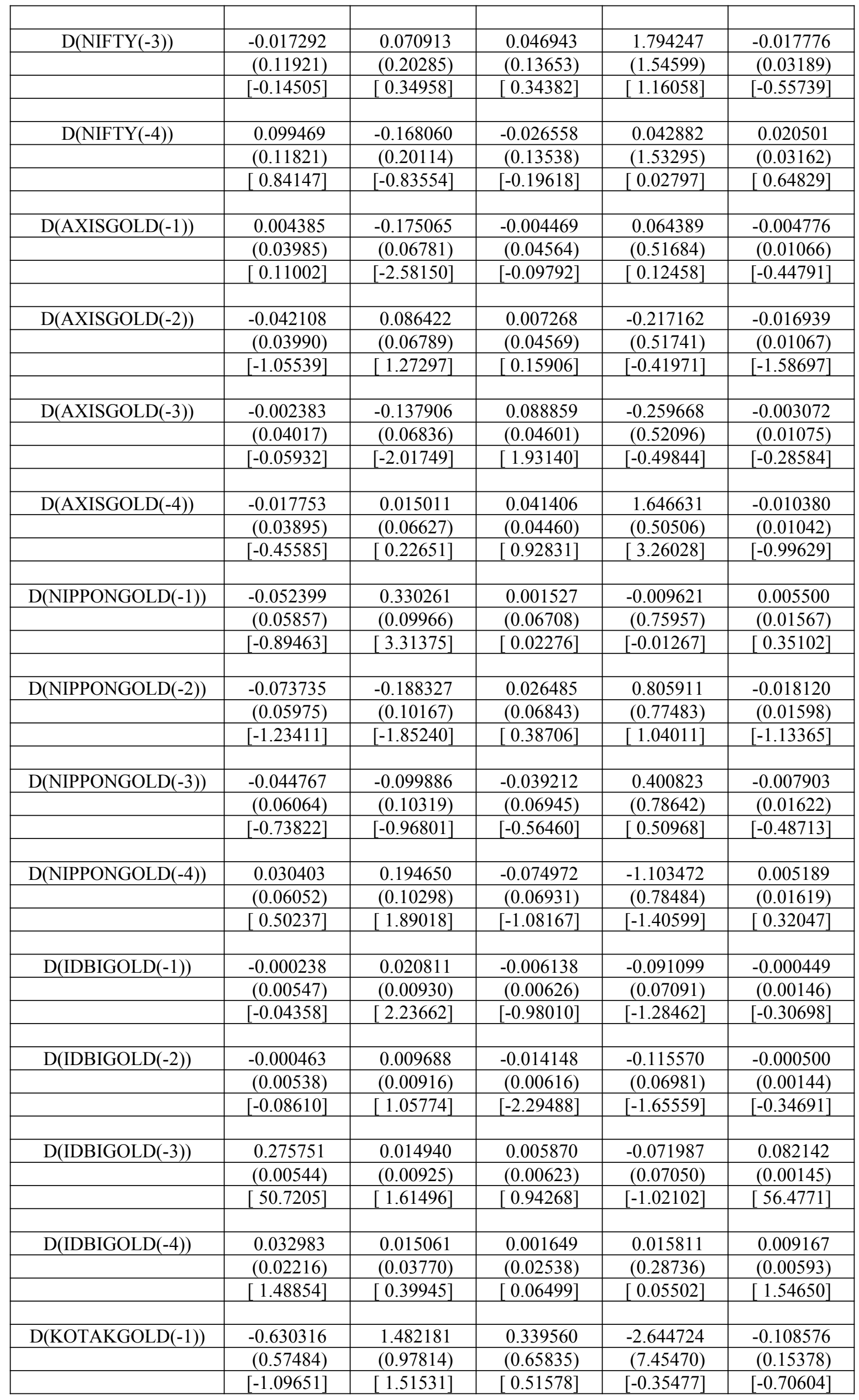




\begin{tabular}{|c|c|c|c|c|c|}
\hline \multirow[t]{3}{*}{ D(KOTAKGOLD(-2)) } & 0.399100 & 0.053826 & 0.163552 & 0.844435 & 0.103969 \\
\hline & $(0.56853)$ & $(0.96740)$ & $(0.65112)$ & $(7.37288)$ & $(0.15209)$ \\
\hline & {$[0.70198]$} & {$[0.05564]$} & {$[0.25118]$} & {$[0.11453]$} & {$[0.68358]$} \\
\hline \multirow[t]{3}{*}{ D(KOTAKGOLD(-3)) } & -0.572394 & -0.186557 & -0.341927 & 20.07617 & -0.165084 \\
\hline & $(0.56586)$ & $(0.96286)$ & $(0.64806)$ & $(7.33824)$ & $(0.15138)$ \\
\hline & {$[-1.01155]$} & {$[-0.19375]$} & {$[-0.52761]$} & {$[2.73583]$} & {$[-1.09053]$} \\
\hline \multirow[t]{3}{*}{ D(KOTAKGOLD $(-4))$} & 0.263072 & 0.026620 & 1.445169 & 9.232590 & 0.052723 \\
\hline & $(0.56947)$ & $(0.96900)$ & $(0.65220)$ & $(7.38507)$ & $(0.15235)$ \\
\hline & {$[0.46196]$} & {$[0.02747]$} & {$[2.21584]$} & {$[1.25017]$} & {$[0.34607]$} \\
\hline \multirow[t]{3}{*}{$\mathrm{C}$} & 1.206723 & 0.930621 & -0.560838 & -20.61517 & 0.219359 \\
\hline & $(0.95837)$ & $(1.63074)$ & $(1.09759)$ & $(12.4284)$ & $(0.25638)$ \\
\hline & {$[1.25915]$} & {$[0.57067]$} & {$[-0.51097]$} & {$[-1.65872]$} & {$[0.85559]$} \\
\hline R-squared & 0.939206 & 0.195139 & 0.085086 & 0.140152 & 0.950328 \\
\hline Adj. R-squared & 0.933403 & 0.118312 & -0.002247 & 0.058076 & 0.945587 \\
\hline Sum sq. Resids & 45836.91 & 132716.1 & 60121.98 & 7708717. & 3280.440 \\
\hline S.E. equation & 14.43432 & 24.56125 & 16.53124 & 187.1887 & 3.861488 \\
\hline F-statistic & 161.8469 & 2.539966 & 0.974276 & 1.707584 & 200.4324 \\
\hline Log likelihood & -977.8959 & -1106.534 & -1010.721 & -1598.023 & -658.8053 \\
\hline Akaike AIC & 8.263602 & 9.326725 & 8.534888 & 13.38862 & 5.626490 \\
\hline Schwarz SC & 8.580779 & 9.643901 & 8.852065 & 13.70580 & 5.943667 \\
\hline Mean dependent & 3.246364 & -0.140289 & -0.363223 & -15.82645 & -1.107851 \\
\hline S.D. dependent & 55.93313 & 26.15730 & 16.51270 & 192.8731 & 16.55400 \\
\hline \multicolumn{2}{|c|}{ Determinant resid covariance (dof adj.) } & 8.318912 & & & \\
\hline \multicolumn{2}{|c|}{ Determinant resid covariance } & 5.162312 & & & \\
\hline \multicolumn{2}{|c|}{ Log likelihood } & -5258.797 & & & \\
\hline \multicolumn{2}{|l|}{ Akaike information criterion } & 44.41154 & & & \\
\hline \multicolumn{2}{|l|}{ Schwarz criterion } & 46.06951 & & & \\
\hline \multicolumn{2}{|l|}{ Number of coefficients } & 115 & & & \\
\hline
\end{tabular}

Above table -3 represents the Vector Error Correction Model of select ETF's and NSE benchmark relationship. Axis Gold, Nippon Gold, Kotak Gold, IDBI Gold acted as dependent variable and Nifty Gold as Independent variable. The result signified that Axis, Gold and IDBI were observed to be negatively correlated, except Kotak was positively correlated with Nifty. Furthermore, the table shows that the error correction terms t-values. In order to check the significant of the relationship Wald test has been applied with the VECM equation.

VECM Equation: D(NIFTY) $=$ C(1)*( NIFTY(-1) - 0.310175254062*AXISGOLD(-1) - 0.22396523388* NIPPONGOLD(-1) $0.0489630115649 *$ IDBIGOLD(-1)+9.00701119408 * KOTAKGOLD(-1) - 1510.85446609$)+\mathrm{C}(2) * \mathrm{D}(\mathrm{NIFTY}(-1))+$ $\mathrm{C}(3) * \mathrm{D}($ AXISGOLD $(-1))+\mathrm{C}(4) * \mathrm{D}(\mathrm{NIPPON}$ GOLD(-1)) + $\mathrm{C}(5) * \mathrm{D}(\mathrm{IDBIGOLD}(-1))+\mathrm{C}(6) * \mathrm{D}(\mathrm{KOTAKGOLD}(-1))+$ $\mathrm{C}(7) * \mathrm{D}(\mathrm{NIFTY}(-2))+\mathrm{C}(8) * \mathrm{D}($ AXISGOLD $(-2))+\mathrm{C}(9) * \mathrm{D}(\mathrm{NIPPONGOLD}(-2))+\mathrm{C}(10) *$ D (IDBIGOLD $(-2))$ $+\mathrm{C}(11) * \mathrm{D}($ KOTAKGOLD $(-2))+\mathrm{C}(12) * \mathrm{D}(\mathrm{NIFTY}(-3))+\mathrm{C}(13) * \mathrm{D}(\mathrm{AXIS} \quad \mathrm{GOLD}(-3))+\mathrm{C}(14) \quad * \mathrm{D}(\mathrm{NIPPONGOLD}(-3))+$ $\mathrm{C}(15) * \mathrm{D}(\mathrm{IDBIGOLD}(-3))+\mathrm{C}(16) * \mathrm{D}($ KOTAKGOLD $(-3))+\mathrm{C}(17) * \mathrm{D}(\mathrm{NIFTY}(-4))+\mathrm{C}(18) * \mathrm{D}(\mathrm{AXISGOLD}(-4))+\mathrm{C}(19) * \mathrm{D}$ $($ NIPPONGOLD $(-4))+\mathrm{C}(20) * \mathrm{D}(\mathrm{IDBIGOLD}(-4))+\mathrm{C}(21) * \mathrm{D}(\mathrm{KOTAKGOLD}(-4))+\mathrm{C}(22)$

Wald test had be farmed by considering the above equation and results were as follows

Null hypothesis: Select ETF's are not having significant Long run relationship with NSE Benchmark of Gold ETF.

Alternative hypothesis: Select ETF's are having significant Long run relationship with NSE Benchmark of Gold ETF.

Table-4: Wald Test for Relationship between Select ETF's and Nifty

\begin{tabular}{|l|l|l|l|l|}
\hline \multicolumn{5}{|c|}{ Wald Test: } \\
\hline & Test Statistic & Value & df & Probability \\
\hline Axis Gold & Chi-square & 6.434343 & 5 & 0.2662 \\
\hline Nippon Gold & Chi-square & 27.07871 & 5 & 0.0149 \\
\hline IDBI Gold & Chi-square & 3169.371 & 5 & 0.0000 \\
\hline Kotak Gold & Chi-square & 9.710961 & 5 & 0.0839 \\
\hline \multicolumn{5}{|c|}{ Restrictions are linear in coefficients. } \\
\hline
\end{tabular}


Source: Secondary Data

Wald test table - 4 indicated that chi square calculated value of the select ETF's namely Axis Gold, Nippon Gold and Kotak Gold are observed to be greater than critical value except IDBI Gold whose calculated value is less than the critical value and the probability value of the above table is statistically significant which signifies, null hypothesis was rejected and alternative hypothesis accepted i.e., Axis Gold, and Kotak Gold was having significant short run relationship with Nifty Gold. While Nippon Gold and IDBI Gold is having longrun relationship with Nifty. Therefore, null hypothesis has been accepted and concluded that there is no long run relationship exist between the ETF with Nifty except in case of IDBI gold.

\section{Objective 2: To know the impact of NSE benchmark on select ETFs}

The study used the Ordinary Least Square (OLS) technique to determine the effect of Nifty on Gold ETFs. The result of the OLS determines whether the NSE benchmark has a significant effect on the Gold Exchange Trade Funds. The study considered four Gold exchange Trade fund based on the market capitalization namely Axis gold, Nippon Gold, IDBI Gold and Kotak Gold. Ordinary least square result as follows

Null hypothesis: There is no significant impact of NSE Benchmark on Axis Gold Alternative hypothesis: There is a significant impact of NSE Benchmark on Axis Gold

Table-5: Impact of NSE Benchmark on Axis Gold

\begin{tabular}{|l|r|r|r|r|}
\hline \multicolumn{5}{|c|}{ Dependent Variable: AXISGOLD } \\
\hline \multicolumn{5}{|c|}{ Method: Least Squares } \\
\hline \multicolumn{5}{|c|}{ Sample: 1 247 } \\
\hline \multicolumn{5}{|c|}{ Included observations: 247 } \\
\hline Variable & Coefficient & Std. Error & t-Statistic & Prob. \\
\hline C & 2127.687 & 83.66394 & 25.43134 & 0.0000 \\
\hline RIFTY & 0.431852 & 0.103783 & 7.051746 & 0.0000 \\
\hline Adjusted R-squared & 0.768723 & Mean dependent var & 2715.693 \\
\hline S.E. of regression & 0.765330 & S.D. dependent var & 117.5442 \\
\hline Sum squared resid & 107.3887 & Akaike info criterion & 12.19885 \\
\hline Log likelihood & 2825422. & Schwarz criterion & 12.22727 \\
\hline F-statistic & -1504.558 & Hannan-Quinn criter. & 12.21029 \\
\hline Prob(F-statistic) & 49.72712 & Durbin-Watson stat & 1.191773 \\
\hline
\end{tabular}

The above table-5 depicts the impact of NSE benchmark on Axis Gold through ordinary least square method. The result indicates that Nifty Gold has a positive and significant impact $(0.431)$ on Axis Gold and the probability value is less than 0.05 , thus it declares that null hypothesis is rejected and alternative is accepted. Further it reveals that Adjusted R-squared value is more than 0.60 which means the model is strong and Durbin Watson lies between 1.5 and 2.5 implies the data is normally distributed.

Null hypothesis: There is no significant impact of NSE Benchmark on Gold Bees

Alternative hypothesis: There is a significant impact of NSE Benchmark on Gold Bees

Table- 6: Impact of NSE Benchmark on Gold Bees

\begin{tabular}{|c|c|c|c|c|}
\hline \multicolumn{5}{|c|}{ Dependent Variable: NIPPONGOLD } \\
\hline \multicolumn{5}{|c|}{ Method: Least Squares } \\
\hline \multicolumn{5}{|c|}{ Sample: 1247} \\
\hline \multicolumn{5}{|c|}{ Included observations: 247} \\
\hline Variable & Coefficient & Std. Error & t-Statistic & Prob. \\
\hline $\mathrm{C}$ & 3206.893 & 57.05632 & 56.20576 & 0.0000 \\
\hline NIFTY & 0.528898 & 0.070777 & -7.472743 & 0.0000 \\
\hline R-squared & 0.885619 & \multicolumn{2}{|c|}{ Mean dependent var } & 2781.951 \\
\hline Adjusted R-squared & 0.882295 & \multicolumn{2}{|c|}{ S.D. dependent var } & 80.98892 \\
\hline S.E. of regression & 73.23589 & \multicolumn{2}{|c|}{ Akaike info criterion } & 11.43331 \\
\hline Sum squared resid & 1314057. & \multicolumn{2}{|c|}{ Schwarz criterion } & 11.46173 \\
\hline Log likelihood & 1410.014 & \multicolumn{2}{|c|}{ Hannan-Quinn criter. } & 11.44475 \\
\hline F-statistic & 55.84188 & \multicolumn{2}{|c|}{ Durbin-Watson stat } & 2.223949 \\
\hline Prob(F-statistic) & 0.000000 & & & \\
\hline
\end{tabular}

Source: Secondary Data

The least square table-6 illustrates the influence of NSE benchmark on Nippon Gold as one of the ETF. The result reveals that the Nifty Gold has a positive influence on the Nippon Gold (0.5288) but the probability value seems to at 5 percent significant level. The Adjusted R squared value is greater than the 0.60 and the Durbin Watson lies within 1.5 to 2.5 , implies the model is strongly fit. Thus, overall result indicates that the null hypothesis is rejected and alternative hypothesis is accepted. 
Null hypothesis: There is no significant impact of NSE Benchmark on IDBI Gold Alternative hypothesis: There is a significant impact of NSE Benchmark on IDBI Gold

Table- 7: Impact of NSE Benchmark on IDBI Gold

\begin{tabular}{|lr|r|r|r|}
\hline \multicolumn{5}{|c|}{ Dependent Variable: IDBIGOLD } \\
\hline \multicolumn{5}{|c|}{ Method: Least Squares } \\
\hline \multicolumn{5}{|c|}{ Sample: 1 247 } \\
\hline \multicolumn{5}{|c|}{ Included observations: 247 } \\
\hline Variable & Coefficient & Std. Error & t-Statistic & Prob. \\
\hline C & 3564.825 & 414.7620 & 8.594870 & 0.0000 \\
\hline NIFTY & -0.254395 & 0.514502 & -0.494449 & 0.0214 \\
\hline R-squared & 0.900997 & Mean dependent var & 3360.432 \\
\hline Adjusted R-squared & 0.903081 & S.D. dependent var & 531.5587 \\
\hline S.E. of regression & 532.3769 & Akaike info criterion & 15.40064 \\
\hline Sum squared resid & 69439160 & Schwarz criterion & 15.42906 \\
\hline Log likelihood & -1899.980 & Hannan-Quinn criter. & 15.41209 \\
\hline F-statistic & 0.244480 & Durbin-Watson stat & 2.131280 \\
\hline Prob(F-statistic) & 0.021432 & \multicolumn{3}{|c|}{} \\
\hline
\end{tabular}

Source: Secondary Data

The above table -7 shows the effect of NSE benchmark on IDBI Gold by a least square method. The result shows that Nifty Gold has a negative effect (-0.2543) on IDBI Gold but the probability value is less than 0.05 , thus announcing the rejection of the null hypothesis and acceptation of alternative hypothesis. This also indicates that the modified R-squared value is over 0.60 and Durbin Watson lies between 1.5 and 2.5, which means that the model is strongly fit.

Null hypothesis: There is no significant impact of NSE Benchmark on Kotak Gold

Alternative hypothesis: There is a significant impact of NSE Benchmark on Kotak Gold

Table- 8: Impact of NSE Benchmark on Kotak Gold

\begin{tabular}{|l|r|r|r|r|}
\hline \multicolumn{5}{|c|}{ Dependent Variable: KOTAKGOLD } \\
\hline \multicolumn{5}{|c|}{ Method: Least Squares } \\
\hline \multicolumn{5}{|c|}{ Sample: 1 247 } \\
\hline \multicolumn{5}{|c|}{ Included observations: 247 } \\
\hline Variable & Coefficient & Std. Error & t-Statistic & 0.0000 \\
\hline C & 130.3954 & 10.94944 & 11.90886 & 0.0000 \\
\hline NIFTY & 0.159212 & 0.013583 & 11.72183 & 258.3142 \\
\hline R-squared & 0.659312 & Mean dependent var & 8.52284 \\
\hline Adjusted R-squared & 0.656697 & S.D. dependent var & 8.131812 \\
\hline S.E. of regression & 14.05440 & Akaike info criterion & 8.143253 \\
\hline Sum squared resid & 48393.91 & Schwarz criterion & 1.316538 \\
\hline Log likelihood & -1002.279 & Hannan-Quinn criter. & \\
\hline F-statistic & 137.4013 & Durbin-Watson stat & \\
\hline Prob(F-statistic) & 0.000000 & \multicolumn{3}{c}{} \\
\hline
\end{tabular}

The least square table- 8 shows the effect of NSE benchmark on Kotak gold as one of the ETFs. The result shows that Nifty Gold has a positive impact on Kotak Gold (0.1592) and the probability value appears to be 5\% significance level. The Adjusted value of the R squared is greater than 0.60 and the Durbin Watson is between 1.5 and 2.5. The final outcome therefore suggests the rejection of the null hypothesis and the adoption of alternative ones.

\section{FINDINGS OF THE STUDY:}

1. In order to determine the relationship between the NSE benchmark and the Gold ETFs, VECM is the statistical tool considered and the study indicates that, during the study period i.e. from 2016-17 to 2020-21, Nippon Gold and IDBI are found to have a long-term relationship with the nifty, which means that there is a strong relationship between them. In the case of Kotak and Axis, a short-term relationship with Nifty indicates that there is a moderate relationship between the variables.

2. Research used Ordinary Last Square methodology to determine the effect of the NSE benchmark on gold ETFs and the result shows that the return performance of nifty has had a significant effect on gold ETFs. During the study period, the coefficient value of IDBI Gold is -0.2543 , implies units increase in nifty will decrease the IDBI gold unit by -0.2543 , while the remaining Gold ETFs are found to have a positive effect in which Nippon is found to have a high effect on Nifty and stated that, Uninformed investors switch to trading baskets of stocks and, therefore, the unfavourable cost of selecting individual stocks increases the availability of these tradable baskets. 
CONCLUSION OF THE STUDY: The study has been emphasized on the impact of benchmark Nifty Bees ETF on the select gold ETFs of NSE India. The study has considered the secondary data from the period of 2016-17 to 2020-21. The study has framed two objectives and applied various statistical methods. The study result states that select gold ETFs from NSE India are having the significant relationship with the Gold ETF benchmark Nifty Bees of NSE India. The study also examined the impact of Gold ETF bench mark Nifty bees on the select Gold ETFs and found that all the selected ETFs are having the significant impact on the growth. Hence there is scope to do research in this area by considering various economic factors which will have influence on different ETFs of NSE India.

\section{BIBLIOGRAPHY:}

[1] Narend. S, M. Thenmozhi (2019), Do Country ETFs Influence Foreign Stock Market Index? Evidence from India ETFs, Journal of Emerging Market Finance, Volume: 18 issue: 1

[2] Purohit, Harsh and Choudhary, Nidhi and tyagi, parul (2015), An Evaluation of Tracking Error on World Indices ETFs Traded in India (June 8, 2015). The IUP Journal of Applied Finance, Vol. 20, No. 3, July 2014, pp. 41-52.

[3] Prabhdeep Kaur Jaspal Singh (2020) Price formation in Indian gold market: Analysing the role of gold Exchange Traded Funds (ETFs) against spot and futures markets, IIMB Management Review Volume 32, Issue 1, March 2020, Pages 5974

[4] Sudindra\& Assistant, (2015). Performance Evaluation of NSE Listed Gold ETF. Indian Journal of Management, Volume 4 Issue 2

[5] Umarani. R \&D.Deepa (2014), Exchange Traded Fund in Indian Stock Market, IOSR Journal of Business and Management (IOSR-JBM) e-ISSN: 2278-487X, p-ISSN: 2319-7668. Volume 16, Issue 2. Ver. I (Feb. 2014), PP 19-23 